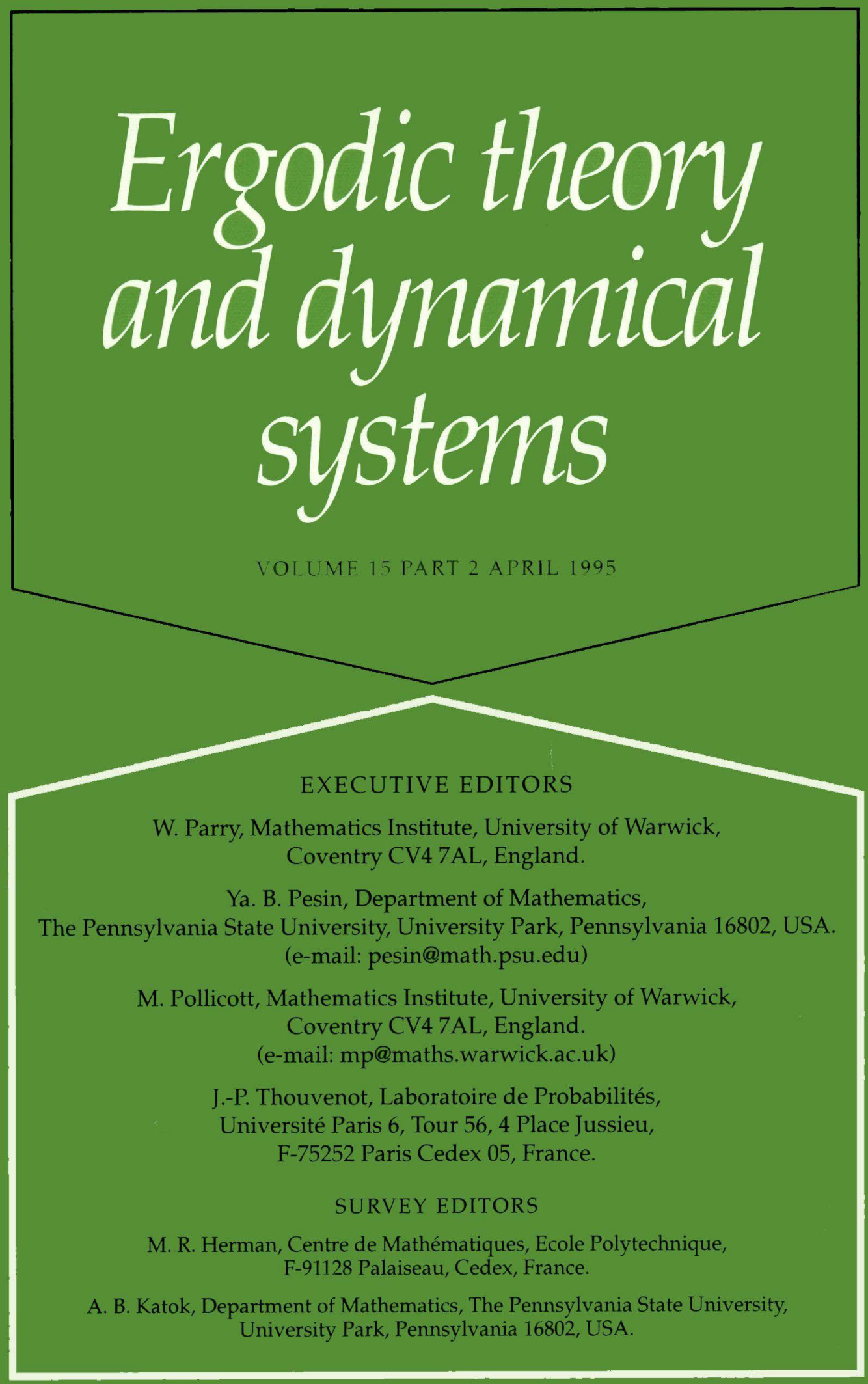




\title{
Ergodic theory and dynamical systems
}

\author{
EDITOR S \\ William Parry Ya. B. Pesin Mark Pollicott J.-P. Thouvenot
}

\section{SURVEY EDITORS}

M. R. Herman A. B. Katok

\section{EDITORIAL BOARD}

S. G. Dani (Tata Institute, Bombay)

W. de Melo (IMPA, Rio de Janeiro)

R. Ellis (University of Minnesota, Minneapolis)

A. Fathi (ENS, Lyons)

J. Franks (Northwestern University)

D. Fried (Boston University)

H. Furstenberg (Hebrew University, Jerusalem)

F. Ledrappier (University of Paris 6)

A. K. Manning (University of Warwick)

B. Marcus (IBM Almaden Research Center, San Jose)

Ergodic Theory and Dynamical Systems provides a focus for this important and rapidly developing area of mathematics and an opportunity to bring together many major contributors in the field which are, at the moment, scattered over a large number of non-specialist periodicals.

Dynamical methods have proved to be a powerful unifying force in mathematics in recent decades, and they are now beginning to be felt in allied subjects such as physics and biology. Ergodic Theory and Dynamical Systems acts as a forum for central problems of differential geometry, number theory, operator algebras, topological, differential and symbolic dynamics, and celestial and statistical mechanics.

Expository survey articles and conference proceedings will be included from time to time and reviews of relevant books will also be published.

Copying: The journal is registered with the Copyright Clearance Center, 222 Rosewood Drive, Danvers, MA. 01923. Organizations in the USA who are registered with the $\mathrm{CCC}$ may therefore copy material (beyond the limits permitted by sections 107 and 108 of US copyright law) subject to payment to CCC of the per-copy fee of $\$ 11.00$. This consent does not extend to multiple copying for promotional and commercial purposes. Code 0143-3857/95 $\$ 11.00+.10$.

Organizations authorized by the Copyright Licensing Agency may also copy material subject to the usual conditions.

For all other use, permission should be sought from Cambridge or the American branch of Cambridge University Press.
G. A. Margulis (Yale University)

K. Petersen (University of North Carolina)

F. Przytycki (Polish Academy of Sciences)

S. M. Rees (University of Liverpool)

D. J. Rudolph (University of Maryland)

D. Ruelle (IHES, Bures-sur-Yvette)

D. Salamon (University of Warwick)

K. Schmidt (University of Vienna)

P. Walters (University of Warwick)

L.-S. Young (University of California, Los Angeles)

Subscriptions: Ergodic Theory and Dynamical Systems (ISSN 0143-3857) is published six times a year in February, April, June, August, October and December. The subscription price (excluding VAT) of volume 15,1995 is $£ 228.00$ (US $\$ 396.00$ in USA, Canada and Mexico) which includes postage. Single parts cost $£ 40.00$ net (US $\$ 70.00$ in USA, Canada and Mexico) plus postage. Members of the London Mathematical Society and American Mathematical Society may subscribe for $£ 114.00$ (US\$198.00). Six parts usually form a volume. EU subscribers (outside the UK) who are not registered for VAT should add VAT at their country's rate. VAT registered subscribers should provide their VAT registration number. Orders, which must be accompanied by payment, may be sent to a book-seller, subscription agent or direct to the publishers: Cambridge University Press, The Edinburgh Building, Shaftesbury Road, Cambridge CB2 2 RU or, in the USA, Canada and Mexico, Cambridge University Press, 40 West 20th Street, New York, NY 100114211. Japanese prices for institutions (including ASP delivery) are available from Kinokuniya Company Ltd, P.O. Box 55, Chitose, Tokyo 156, Japan. Second class postage paid at New York, NY and additional mailing offices. POSTMASTER: send address changes in USA, Canada and Mexico to Ergodic Theory and Dynamical Systems, Cambridge University Press, 110 Midland Avenue, Port Chester, New York, NY 10573-4930, USA.

\section{(C) Cambridge University Press 1995}

\section{CAMBRIDGE UNIVERSITY PRESS}

The Pitt Building, Trumpington Street, Cambridge CB2 1RP

40 West 20th Street, New York, NY 10011-4211, USA

10 Stamford Road, Oakleigh, Melbourne 3166, Australia 